Article

\title{
The Impact of Multimarket Competition on Innovation Strategy: Evidence from the Korean Mobile Game Industry
}

\author{
Jinju Lee ${ }^{1, *}$, Jin Suk Park ${ }^{1, *}$ and Jeonghwan Lee ${ }^{2}$ \\ 1 School of International Corporate Strategy, Hitotsubashi University Business School, 2-1-2 Hitotsubashi, \\ Chiyoda-ku, Tokyo 101-8439, Japan \\ 2 Department of International Business and Trade, Myongji University, Seodaemun-gu, Geobukgol-ro, 34, \\ Seoul 03674, Korea; tankee@mju.ac.kr \\ * Correspondence: jlee@ics.hub.hit-u.ac.jp (J.L.); jpark@ics.hub.hit-u.ac.jp (J.S.P.)
}

Received: 31 December 2019; Accepted: 19 February 2020; Published: 21 February 2020

\begin{abstract}
Multimarket contact (MMC) refers to the situation in which more than two firms simultaneously compete with each other in multiple products and/or geographical markets. Most studies on MMC have explored how the market overlap creates "mutual forbearance", which lessens the intensity of rivalry. While prior studies have mainly focused on how reduced rivalry from MMC influences market-related decisions, only a few have paid attention to its impact on innovation activities. The purpose of this research is to explore how multimarket competition influences different stages of innovation. Specifically, we focus on three stages of innovation: Content development, commercialization, and protection of IPs (Intellectual Property). This study is conducted as an exploratory case research based on the in-depth analysis of two leading Korean Mobile game companies. Based on our findings, we explain how mutual forbearance and observability of the rival's competitive action influence the choice of strategic decisions across different stages of innovation.
\end{abstract}

Keywords: multimarket contact; mobile game industry; innovation strategy; competitive dynamics

\section{Introduction}

Firms often encounter the same rivals across multiple geographical and product markets. For example, Apple and Samsung compete in several electronic product markets, in the same way that Coca-Cola and Pepsi face each other in a number of regional markets. Over the years, strategy scholars have shown that multimarket contact (MMC) between the same rivals leads to different strategic responses. Yu and Canella [1] found that the speed of strategic response to a multipoint rival was faster compared to other rivals. Studying 45 firms in the U.S. personal computer industry, Kang, Bayus and Balasubramanian [2] provided evidence that the existence of frequently encountered rivals influences pricing and new product development decisions.

More recent studies explore how MMC influences innovation-related activities in a high-tech context. The market overlap is known to increase competition for acquiring valuable knowledge-based resources and the likelihood of taking protective measures (i.e., patent lawsuit) [3]. These studies suggest that MMC findings can be extended and applied to other contexts with different industry characteristics and value chain activities (e.g., upstream versus downstream).

\subsection{Research Questions}

One of the underexplored contexts of MMC studies is the mobile game industry-an industry characterized by creative products that are commercialized through various platforms and is 
often protected by IP (Intellectual Property) rights. Similar to other digital game industries [4], the innovation process in the mobile game industry mainly involves content development and content commercialization (publishing and distribution). In addition, a unique phenomenon increasingly observed in the online game industry is the protection of their IPs. Given this, the goal of this research is to investigate how MMC between two leading rivals in a game industry influence their strategic decisions across different stages of the innovation process. We aim to address the following research question:

How do rivals strategically react to multimarket contact-based competition across different stages of innovation (content development, content commercialization and content protection)?

\subsection{Research Scope and Method}

We investigate the impact of MMC between two leading rivals in the Korean mobile game industry. The mobile game industry has grown a fast pace, along with the increased accessibility of smartphone devices. According to the Korea Creative Content Agency, the estimated market size of the global mobile game was USD 57.6 billion in 2017. China represented the highest market share $(20.7 \%)$, followed by Japan (16.4\%), U.S. (15.6\%), and South Korea (9.5\%). Being the fourth largest mobile game market in the world, the South Korean market has been successful in nurturing competitive mobile game companies. As of 2018, there are 34 game companies listed in the Korean stock market. Among them, in terms of the market value, two significant major players are Netmarble (market value at about USD 13 billion) and NCSoft (about USD 8 billion). Netmarble and NCSoft are considered as rival giants, known to have multipoint contact in a number of regional and product markets.

A case-based exploratory approach is conducted to illustrate the dynamics and consequences of MMC between these two firms. We chose this method for several reasons. First, competitive interactions between firms are time-based, multi-faceted, and complex. A case study would thus be appropriate for capturing and disentangling the complex interaction between two firms [5]. Second, our main goal is to refine the existing framework of MMC studies to suit the digital content industry. The nature of our inquiry is theory-building, rather than theory-testing. Therefore, a qualitative approach better served our purpose for developing richer insights regarding the phenomenon [6].

We mainly collected secondary materials for our analysis. Public information was gathered from each company's annual reports and industry reports published by the Korea Creative Content Agency for the immediately preceding five years (2014-2019). We also collected related news and industry magazine articles to gather supplementary information about each company, as well as interpretive views from different industry stakeholders. After collecting all the information, we initially analyzed the key events in a chronological order, and thereafter identified emerging themes that are related our research. The theoretical interpretation of the phenomenon was interactively discussed among authors. Here produced is an outcome that is a fine-grained representation of our analysis.

\section{Theoretical Background and Framework}

\subsection{Concept of Multimarket Contact (MMC)}

Multimarket contact (MMC) refers to the situation in which more than two firms simultaneously compete with each other in several product and/or geographical markets [1,7]. With the acceleration of globalization, market overlap between rivals has become salient, leading to the intensification of rivalry between competing firms. As firms under intensified rivalry tend to closely monitor their rivals' strategic behaviors and take following corresponding actions, understanding MMC and its strategic implications are considered as one of the critical issues in the strategy field today [2,8]. In this research, we consider the overlap in the mobile game product genre to decide the degree of MMC. 


\subsection{MMC and Mutual Forbearance}

Figure 1 represents the traditional framework of MMC and its consequences. Majority of the MMC studies investigate how the market overlap creates "mutual forbearance", which lessens the intensity of rivalry or the frequency of retaliatory actions $[9,10]$. The central argument of mutual forbearance is that rivals competing in overlapping markets will seek ways to reduce the risk of costly retaliation. For instance, Gimeno [11] found that global airlines choose to enter markets following key rivals' footholds to reduce the intensity of rivalry in their main (hub) markets. The expected risk associated with retaliation is commonly observed in various market-related decision making processes, such as pricing, product, and market choice.

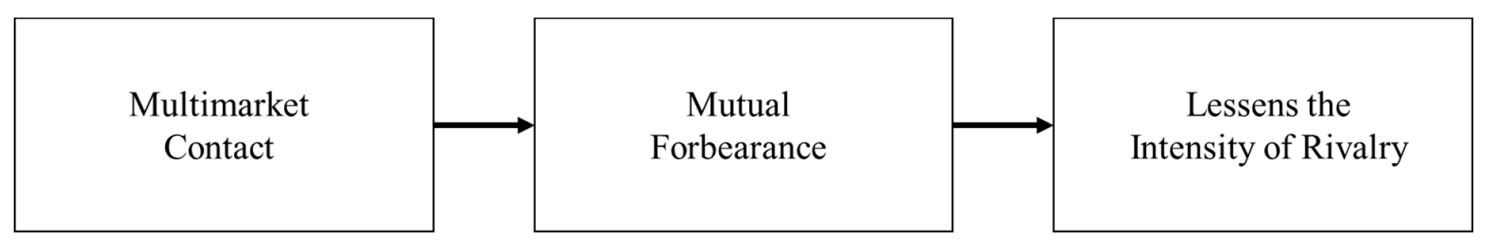

Figure 1. Traditional Framework of MMC and its Consequences. Source: Authors' illustration based on the literature review.

Some studies have shifted the attention to upstream activities (e.g., R\&D), pointing out that prior research on MMC have been limited to implications on downstream activities (i.e., pricing, market entry decisions). In the medical devices industry, Theeke and Lee [3] found that an increased level of $\mathrm{MMC}$ is likely to initiate a patent lawsuit against the focal firm's rival. Other studies have also found that the perceived threat of imitation entailed by increased rivalry can also encourage firms to enact protective measures against these industry threats, such as patenting [10]. In a similar vein, Anand, Mesquita and Vassolo [12] argued that the notions of exploitation and exploration offer insightful explanations regarding the different impacts of the mutual forbearance hypothesis. The research made an interesting observation that high-tech firms facing high uncertainty risk of exploration perceive their rival's presence as a signal for market growth potential. This result suggested that the impact of MMC can be context-specific, conditioned with different types of corporate activities. As they pointed out, previous research on multimarket contact has largely focused on "exploitation", rather than "exploration" activities. In their research, they further specified that, "This gap is highly problematic, since most strategists subscribe to the idea that innovation and exploration are not tantamount to interfirm competitive dynamics; they are also the underlying engine of industrial, strategic, and organizational competitiveness (p. 802) [12]". Building on this line of work, different organizational outcome domains, such as innovation, are also worth noting [3,12]. In this regard, we aim to refine prior studies by consolidating both upstream and downstream activities and explore how MMC influences the different stages of upstream and downstream innovation activities.

\subsection{Stages of Innovation Activities and Observability of Competitive Actions}

Upstream activities are commonly described as concerning resource acquisition and development, including functional activities at the beginning stage of the value chain (e.g., new product development, $R \& D)$. Downstream activities involve the commercialization or exploitation of resources which includes functional activities at the end stage of the value chain (e.g., sales, after services).

Table 1 includes the key descriptions of upstream versus downstream activities, the expected level of observability of rivals' actions, and the predicted likelihood of mutual forbearance. The observability of rivals' action is commonly understood as a crucial enabler for mutual forbearance [10]. We refine this assumption by applying different degrees of observability to different streams of a firm's innovation activities [13]. Upstream activities are mainly operated within the organizational boundaries, thus making it less observable for key rivals and other external stakeholders. Therefore, it is highly likely that mutual forbearance will not exist. On the other hand, downstream activities largely involve 
interaction with external stakeholders (i.e., customers), making it more observable from outside the organization. Thus, it is highly likely that mutual forbearance will exist in downstream activities.

Table 1. Upstream vs Downstream Activities, Observability, and Mutual Forbearance.

\begin{tabular}{ccccc}
\hline & Examples & $\begin{array}{c}\text { Observability by } \\
\text { Rivals }\end{array}$ & $\begin{array}{c}\text { Likelihood of } \\
\text { Mutual } \\
\text { Forbearance }\end{array}$ & $\begin{array}{c}\text { Likelihood of } \\
\text { Retaliatory } \\
\text { Actions by Rivals }\end{array}$ \\
\hline Upstream activities & $\begin{array}{c}\text { R\&D, New Product, } \\
\text { Development }\end{array}$ & Low & Low & High \\
\hline $\begin{array}{c}\text { Downstream } \\
\text { activities }\end{array}$ & $\begin{array}{c}\text { Sales Operation, } \\
\text { Distribution }\end{array}$ & High & High & Low \\
\hline
\end{tabular}

Source: Authors' analysis based on the literature review.

\subsection{Stages of Innovation Activities in the Mobile Game Industry}

Figure 2 illustrates the stages of innovation activities and the observability of actions for each stage. The content development process is inclusive of game concept and pitch development, game design, and production and prototype planning activities. These are typically in-house activities that are not disclosed to public audiences. Since this is still an early stage of product development, numerous ideas are exchanged during this stage; it is considered to be highly uncertain and risky. It is hard for firms to track or anticipate their rivals' latest product development activities, thereby imposing less visible threats to their competitors. In addition, cultural production is known to encounter greater market uncertainty because customer preferences are difficult to predict [14,15]. Mobile game companies typically choose different types of commercialization strategies for their products in different markets. General forms of commercialization strategy include: (1) Direct service through IOS or Android app stores; (2) using intermediate platforms (e.g., Kakao or Line), or; (3) publishing through local companies by permitting licensing. Commercialization related actions are more visible in the market and can be perceived as direct threat to competitors. IPs in the mobile game industry include technology patents, trademarks, design patent, and copyrights. Examples of IPs vary from program source code to the main game character's name and appearance. Mobile game developer King, famous for the world-wide hit game Candy Crush Saga, is known for successfully trademarking the word 'candy' to prohibit other game developers from using the work in their game titles [16]. The information of filed patents and IPs are generally open to the public. Therefore, the observability of actions associated with the protection of IPs is relatively high in the stage.

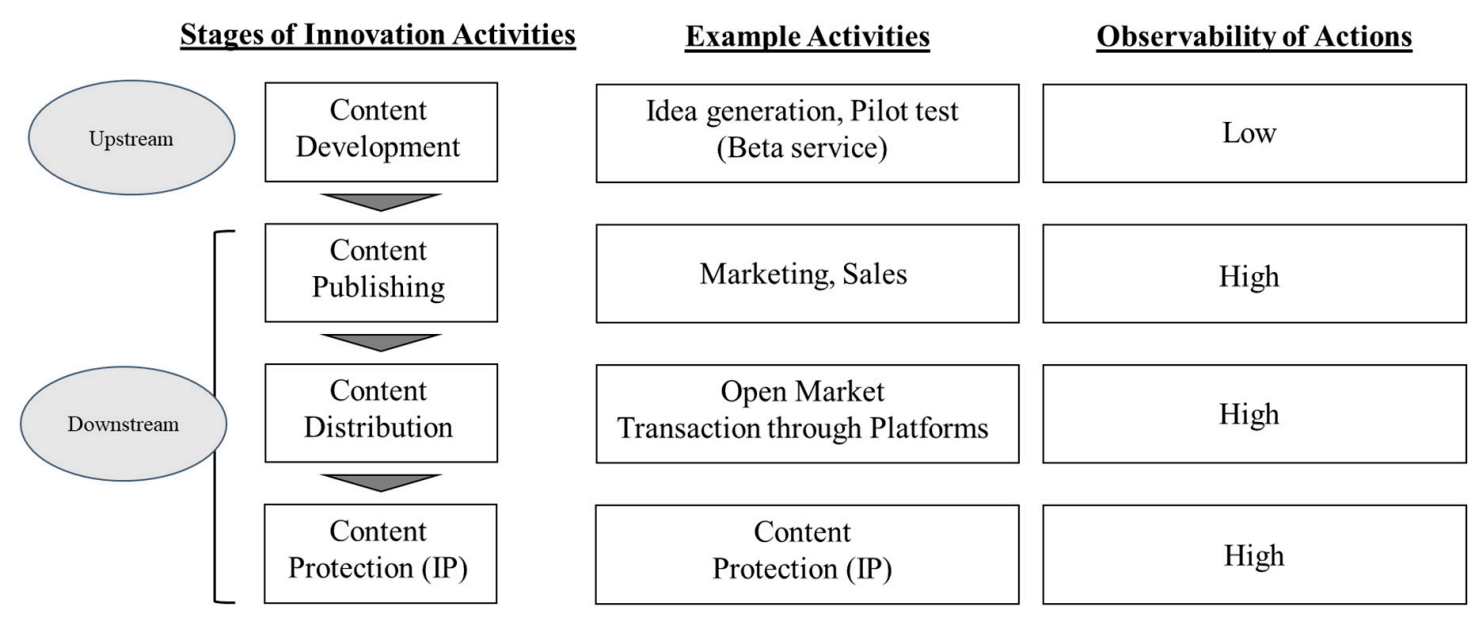

Figure 2. Stages of Innovation Activities in the Mobile Game Industry. Source: Authors' analysis based on the literature review. 


\section{Research Context}

This study is a case-based research upon an industry and firm-level analysis. The mobile game industry is a suitable context to this study since on-going upstream and downstream innovation activities are observable for a broad set of firms.

\subsection{Overview of the Korean Mobile Game Market}

According to the Korea Creative Content Agency [17], the estimated market size of the South Korean game industry in 2018 was about USD 14 billion. Within the Korean game industry, the mobile game sector accounts for the largest portion, taking 48\% (USD 6.6 billion) of the industry. Along with domestic market growth, the size of exports has likewise been steadily growing. The total size of game export in 2017 was estimated to be around USD 5.9 million, with the mobile game sector also being the most significant contributor (54\%, USD 3.2 million). With their high growth potential, major Korean game companies are strategically focusing on investing more resources into their mobile game products. Simultaneously, they are seeking to expand their target market into other countries. Among the key export countries, the Greater China area accounts for $37.6 \%$ and Japan accounts for $18.4 \%$, which is more than half $(56 \%)$ of the total export.

\subsection{Netmarble}

Founded in South Korea in 2000, Netmarble mainly focuses on the mobile game developing and publishing business. In 2018, Netmarble's sales revenue was around USD 2 billion, with operating profit of around USD 0.2 billion. According to the mobile app research firm App Annie, Netmarble was listed as among the top 5 game publishers, along with Tencent (China), NetEase (China), Blizzard (U.S.), and Bandai Namco (Japan). Netmarble's main business model is to increase the customer base by providing free download games. Its main revenue stream is generated by in-app-purchase of game items by users.

Netmarble's top three income generating games are Lineage 2: Revolution, MARVEL Contest of Champions, and Seven Knights (See Figure 3) [18]. One of the key factors of Netmarble's success was to acquire IP rights from other companies and develop those into a good mobile game. For example, the rights to use IPs from Lineage 2: Revolution was contracted from NCSoft, while that of MARVEL Contest of Champions was from Disney. Netmarble is also making aggressive investments in game content developing companies. It was affiliated with 12 domestic game developers and 6 overseas game developers (including publishers) across Canada, U.S., and Columbia. The overseas developers were all acquired in 2016 and 2017.

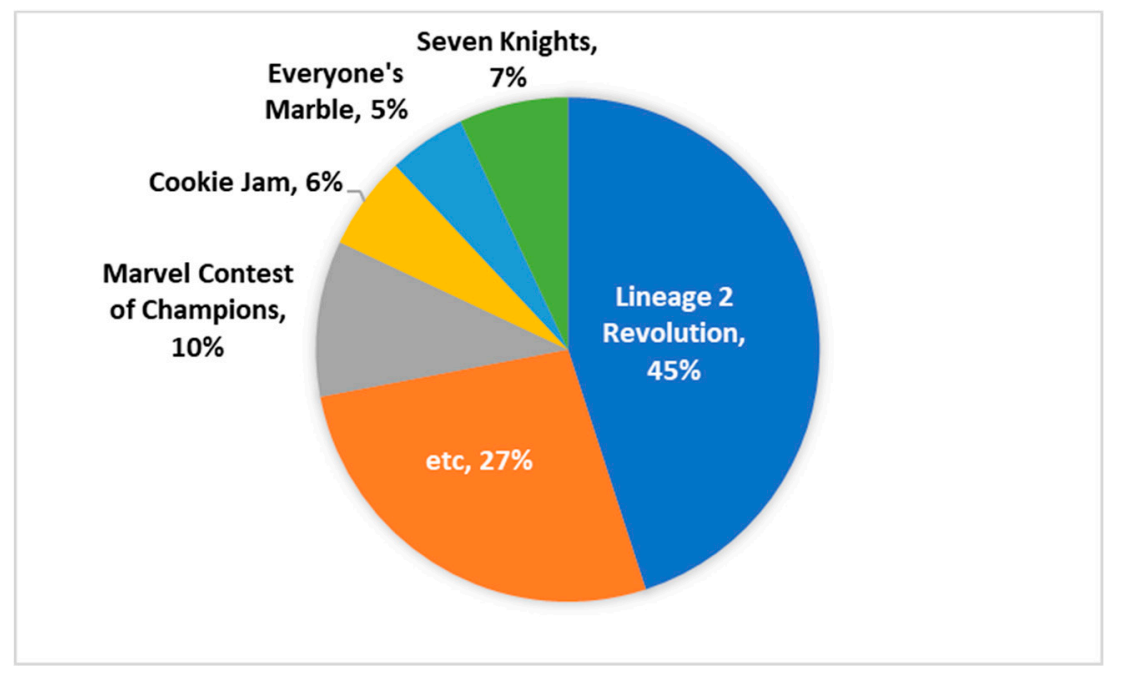

Figure 3. Sales Breakdown by Products (\%) [18]. Graph created by the authors. Source: [18]. 
Netmarble's sales revenue is mainly generated from the overseas market. In $2018,70 \%$ of its sales revenue came from overseas. The ability to localize its products is one of Netmarble's strong competitive advantages over its main competitors. For example, as part of its localization strategy, Netmarble hires popular Japanese voice actors to voice each main character when games are launched in Japan. Netmarble also created a new character as a main narrator specifically for the Japanese version because they understand that Japanese game users are more used to interacting with one narrator who makes users feel less lonely. Within Netmarble, this localization strategy is labeled as the "Multi-Build" strategy, which covers fine-tuning products for local users' game playing style, character customization, pricing strategy, and other marketing campaigns [18].

Netmarble entered the Japanese market in 2000 through direct entry, establishing its own subsidiary, Netmarble Japan Inc. As of 2018, Netmarble has provided five mobile game services in Japan through the IOS and Android platforms. Among them, Lineage 2: Revolution, which was released in 2017 has achieved accumulated sales revenue of over USD 500 million. This took other competitors by surprise, given that the Japanese market was considered to be the most difficult to penetrate in Asia. As mentioned above, successful localization efforts were made to cater to the specific needs of Japanese customers. Given that Japanese customers are more attached to the main characters, famous voice actors were casted and a main NPC (Non-Player Characters) was added to provide more personal guidance to users. A day after its release, Lineage 2: Revolution was ranked as the number one downloaded mobile game in Japan. To continue its success, Netmarble Japan Inc. is also launching customized games based on IPs that Japanese customers are familiar with. The King of Fighters, a popular arcade game originally made in Japan has been repackaged as a mobile game and published by Netmarble.

Netmarble was faced with a different type of challenge in China. After Korea's deployment of the Terminal High Altitude Defense (THAAD) missile system, Korean mobile game companies were allegedly penalized and restrained from releasing their games in China since March 2017. Netmarble has since been unable to launch new games in China, as its request to do so was denied by the Chinese government. Compared to other game companies struggling to resolve this problem, Netmarble made a swift strategic decision to change its market focus to other regions such as the U.S. and Japan. Industry analysts and media have positively evaluated this strategic change, stating that it enabled Netmarble to minimize the potential loss caused by the sanction. However, with China being the largest and fastest growing market, Netmarble is still seeking other ways to enter the market. To bypass the sanction, Netmarble is attempting to enter the Chinese market through its subsidiary in the U.S. It is likewise seeking to utilize its second largest shareholder, Tencent to politically resolve the issue.

\subsection{NCSoft}

NCSoft was founded in 1997 and launched its first PC online game Lineage in the following year. Traditionally, NCSoft was famous for pioneering the market for online MMORPG (Massively Multiplayer Online Role-playing Games) for PC users. This game gained its popularity by being the first to introduce the castle siege battle to game users. With this, hundreds of people could join and enjoy the castle siege event by forming multiple alliances with other guilds. As the market for the mobile game sector continued to grow quickly and largely, the company strategically began to shift towards the mobile game market. In 2018, NCSoft's sales revenue was around USD 1.7 billion, with an operating profit of around USD 0.6 billion. A large portion of the sales revenues came from the mobile game sector $(53 \%)$, followed by online games $(28 \%)$, and loyalty income $(16 \%)$. NCSoft's top products were Lineage and Lineage2, which accounted for about $10 \%$ of the total revenue (See Figure 4) [19]. With Lineage being a massive success, NCSoft's product strategy was more focused towards continuous improvement and maintenance of their own IPs. The company also uses a licensing strategy to exploit its existing IPs and generate extra income. Through this, licensing is contracted out for a certain period with a loyalty fee agreement under which payment is made based on a certain percentage of the contractor's sales revenue. 


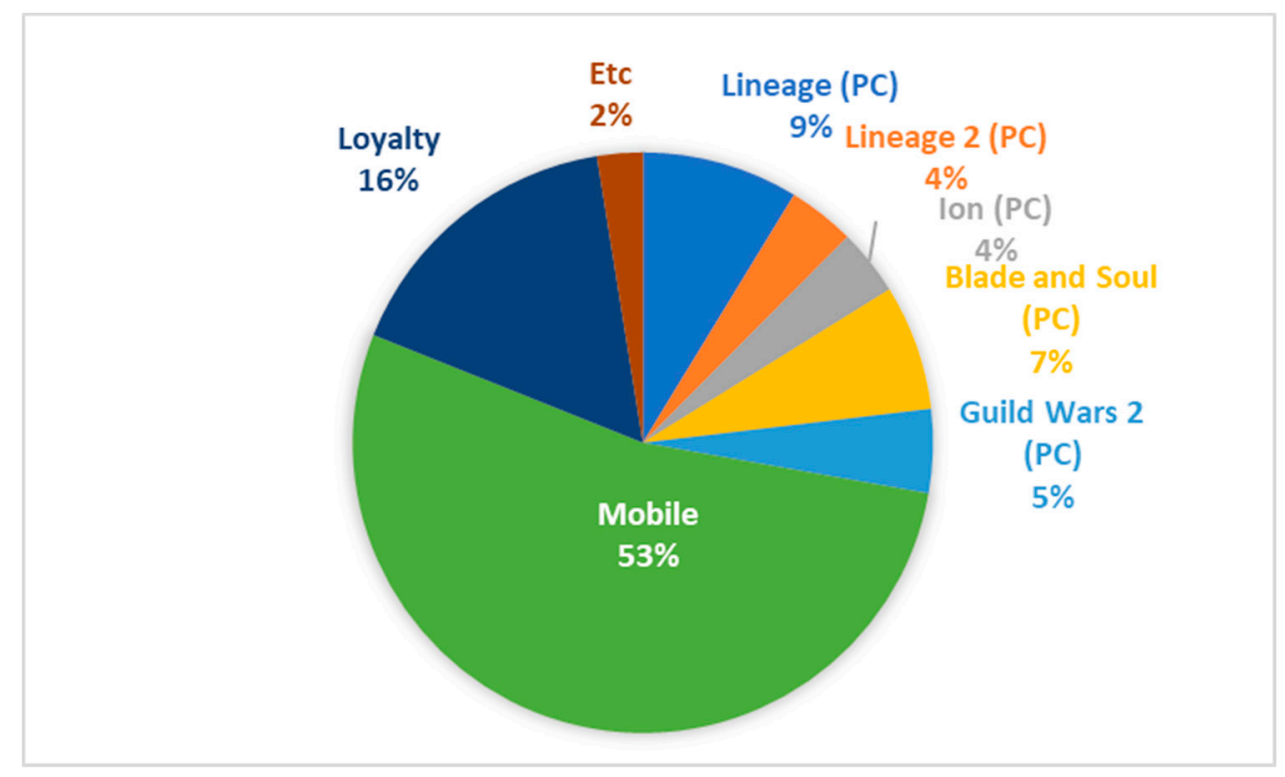

Figure 4. Sales Breakdown by Products (\%) [19]. Graph created by the authors. Source: [19].

NCSoft's first global expansion attempt was to enter the Taiwanese market. In 2000, the online PC game Lineage was launched in Taiwan, with its local business partner Ganamia taking charge of publishing. Since the product launch, approximately 9 million local users have enjoyed the game; it is considered to be a success case in the online game industry. In June 2017, NCSoft launched its MMORPG mobile game Lineage through its wholly-owned subsidiary in Japan. In Korea where the product was first launched, it has been ranked as the most downloaded mobile game application for 23 consecutive months. In Taiwan, it was also ranked as the most downloaded mobile game application for 15 consecutive months. The service launched in Japan in June 2017. It gathered over 183 million users on the first day, owing to a pre-registration promotion before the official launch.

China has been one of NCSoft's target markets for expanding its online PC game products. In 2012, NCSoft formed a publishing agreement partnership a local Chinese company KongZhong, to service Guild Wars 2. In the following year, Blade and Soul started its service in China. The mobile game version of Blade and Soul was launched in China in 2016. In the same year, NCSoft formed a partnership with a local company, Alpha group, to publish its game, Lineage Red Knights. Since March 2017, NCSoft has also struggled to get permission from the Chinese government to release its games in the Chinese market.

\subsection{Comparison between Netmarble and NCSoft}

NCSoft's product strategy seems to be explained by the idea of exploitation as its activities are concentrated on its long-lasting competitive IP, Lineage. To a certain extent, majority of its products are a variation of the original hit product that was launched in 1998 and has since been expanded into multiple platforms. In contrast, its key rival Netmarble focuses more on partnerships to acquire competitive IPs, rather than investing to develop its own. In fact, Netmarble is one of the major licensees of NCSoft's Lineage. Lineage 2: Revolution, one of the key products of Netmarble is based on Lineage and co-developed jointly by the two companies. Another strategic difference between the two is that NCSoft actively forms partnerships with local publishing companies whereas Netmarble uses its own wholly-owned subsidiaries to publish its games in Japan and China. Partnerships gives more strategic flexibility and access to local market information but less autonomous control for making critical decisions or protecting its knowledge. Whereas wholly-owned subsidiaries give the headquarters more autonomy and can better protect internal knowledge, they give less strategic flexibility for reacting to external environmental change. In terms of visibility, partnerships are more visible than wholly-owned ownership because stakeholders can track events through public announcements 
between the partners. Therefore, we will consider the type of ownership in the overseas market as one of the competitive action decisions influenced by rivalry. As McGrath, Chen and MacMillan [20] argued, market information can become a valuable resource and having more control of private information may increase the rivalry between two firms. Table 2 illustrates the comparison of the key financials and strategic focus for both firms.

Table 2. Comparison between Netmarble and NCSoft.

\begin{tabular}{ccc}
\hline & Netmarble & NCSoft \\
\cline { 2 - 3 } & FY 2018 & FY 2018 \\
\hline Total Asset (US\$ million) & 5433 & 2941 \\
\hline Sales (US\$ million) & 2021 & 1715 \\
\hline Operating Profit (US\$ million) & 241 & 614 \\
\hline Net Income (US\$ million) & 214 & 421 \\
\hline Main Game Genre & MMORPG & MMORPG \\
\hline Key Strategy & $\begin{array}{c}\text { Partnership with other } \\
\text { developers/publishers }\end{array}$ & $\begin{array}{c}\text { Exploitation of its own IP, } \\
\text { In-house development } \\
\text { Key Market }\end{array}$ \\
\hline
\end{tabular}

Table creation and analysis conducted by the authors, Sources: $[18,19]$.

\section{Findings}

\subsection{Multipoint Competition between Two Firms}

In addition to the analysis above, we conducted a separate analysis of how the multipoint competition between Netmarble and NCSoft evolved over the recent three years. The competitive dynamics between the two firms was first initiated in 2017, when NCSoft entered the Korean mobile game industry. Since then, the two firms have competed in multiple product markets and geographical regions. We firstly listed each company's mobile game product genre, which they each launched in Korea, Japan, and China, to compare the degrees of MMC. We found that the game product genre overlapped the most in Korea. Table 3 shows MMC in terms of game product genre. We also investigated the MMC in other geographical locations, such as Japan and China, and found less of a genres overlap. For example, in Japan, there was only one genre overlap (MMORPG). Therefore, between Netmarble and NCSoft, Korea had the highest MMC, which means that in theory these firms should exhibit the strongest mutual forbearance behavior against each other. In the following analysis, we investigate how MMC influenced their different stages of innovation.

Table 3. Analysis of the Multimarket Contact.

\begin{tabular}{|c|c|c|}
\hline & & List of Game Product Genre As of 2019 \\
\hline \multirow[t]{2}{*}{ Number of Game Product Genre } & Netmarble (9) & $\begin{array}{l}\text { MMORPG (Massively Multiplayer Online } \\
\text { Role-Playing Game), Action RPG, Action } \\
\text { Strategy RPG, RPG, Board Game, } \\
\text { Catching RPG, Poker, MOBA } \\
\text { (Multiplayer Online Battle Arena), Sports }\end{array}$ \\
\hline & NCSoft (4) & MMORPG, RPG, Sports, Puzzle \\
\hline \multicolumn{2}{|c|}{ Game Product Genre Overlap (3) } & MMORPG, RPG, Sports \\
\hline
\end{tabular}




\subsection{Content Development Stage}

When mutual forbearance occurs, firms are expected to act less aggressively to avoid any competitive actions from their key rivals. Conversely, when mutual forbearance is absent, firms are expected to aggressively compete against their rivals. The degree of observability of a given rival's action triggers mutual forbearance (i.e., firms are highly likely to act upon mutual forbearance when they can directly observe and predict their rival's activities).

In the mobile game industry, competitive actions in the content development stage can be observed in two different ways. We can firstly observe how firms develop contents either internally or through external resources. As rivalry increases without mutual forbearance, more aggressive forms of competitive dynamics for acquiring content development-related resources, such as the acquisition of small game companies or equity investment to local game development companies, will be observed. In Netmarble's case, the acquisition of content development firms was more salient in geographical locations (e.g., Canada) where there was less contact with NCSoft. In addition, Netmarble took aggressive measures to acquire popular local IPs in low MMC geographical locations such as the U.S. and Japan. NCSoft also invested equity into content development firms in countries with low MMC. For example, Guild Wars was developed by ArenaNet—one of its subsidiaries in the U.S.

In Korea, where there is high MMC and mutual forbearance, we observed the diversification of game portfolios. Netmarble is intentionally diversifying its game portfolio with different types of genres. As shown in Figure 5, 47\% of Netmarble's sales are generated from MMORPG, followed by other types of RPG (25\%), Casual (22\%), and others (6\%). NCSoft is also trying to diversify its mobile game product portfolio. In 2017, NCSoft launched Pro Baseball H2, deviating from its traditional strength (MMORPGs) by expanding into the sports management game genre.

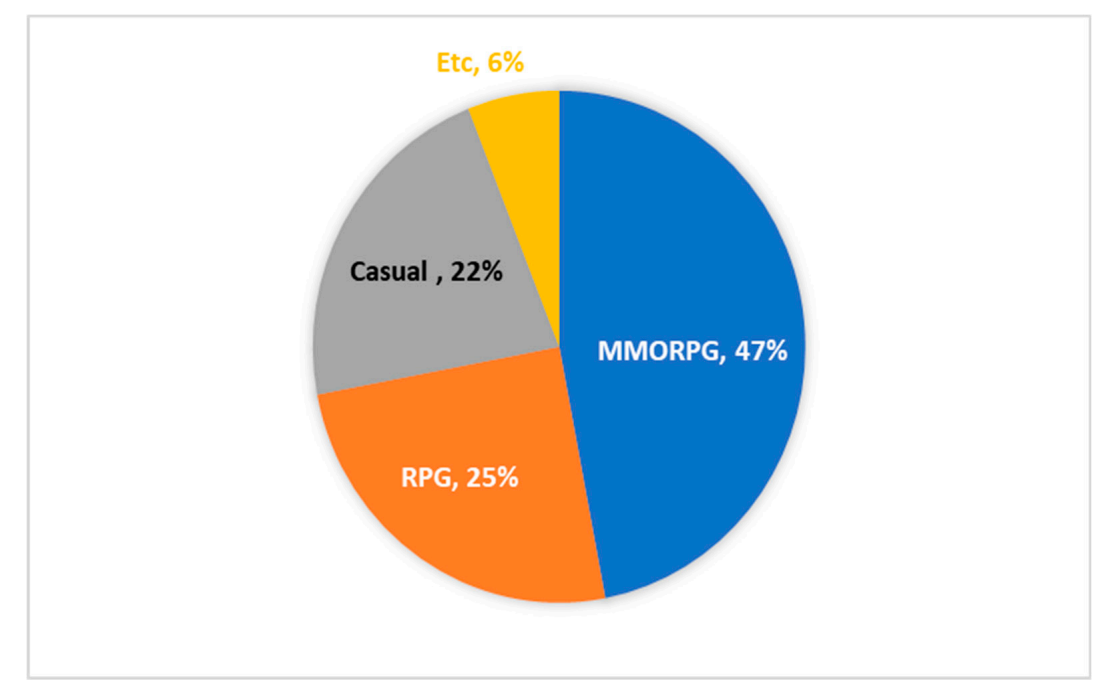

Figure 5. Sales Breakdown by Game Genres (\%) [18]. Graph created by the authors. Source: [18].

\subsection{Commercialization Stage (Publishing and Distribution)}

The commercialization strategies that are used by mobile game companies can differ in terms of usage of publishers and platforms and their pricing strategies. As mentioned previously, commercialization-related actions are more visible in the market and can be perceived as direct threats to competitors. The actions taken by Netmarble and NCSoft differ between Korea and other countries. For locations with low MMC (less mutual forbearance), both Netmarble and NCSoft chose to establish wholly-owned subsidiaries to deal with local operations. In addition, both firms chose to publish their games through direct application services platforms: IOS and Android. Since visibility is greater in this stage, having a wholly-owned subsidiary rather than using a market contract a way to preserve private information that is related to commercial activities, such as the marketing and localization of 
products [21]. For example, Netmarble's know-how and rationale for hiring local Japanese voice actors and including a more intimate interaction interface might have been diffused through different market agencies if it had chosen to use a market contract. NCSoft also established internal autonomy rather than to using a market contract with outside vendors. Notably, the situation in China is somewhat different from that of Japan; because the Chinese Government has not been issuing new service licensing rights to any Korean game companies, the two firms have been struggling to service their products in China. To remedy this situation, Netmarble is seeking to partner with a local Chinese firm to bypass the restriction, whereas NCSoft was initially waiting for the Chinese Government to change its stance and grant the issue but is now looking for a local partnership as well.

\subsection{IP Rights Protection Strategy}

According to Theeke and Lee [3], under an MMC, the threat of retaliation, which generally leads to mutual forbearance in downstream rivalry, will not be sufficient to withhold firms from protecting their IPs in upstream rivalry. Therefore, as multimarket competition increases, patent filings and patent litigations will be more prominent among those who are competing in the same markets. We also found similar evidence in our case study.

According to Netmarble's 2018 annual report, they hold 449 trademarks and 44 patents, inclusive of those in the application stage. Within the 439 trademarks, $173(38 \%)$ are overseas, and within 44 patents, $7(16 \%)$ are overseas. Netmarble holds an additional 9 design rights and 320 copyrights in Korea (See Table 4). NCSoft has been using licensing strategies to protect and exploit its IPs. Loyalty income that has been generated from its IPs has recently increased more than two-folds: from USD 122 million in 2016 to USD 282 million in 2018 (See Figure 6). Beyond the actions taken above, NCSoft has also filed a lawsuit litigation against Netmarble, claiming a violation of the IP within Netmarble's new game products. Therefore, the findings here align with those of prior studies that reconfirmed that MMC tends to increase the level of rivalry over knowledge-related resources and nullify the mutual forbearance; this is mainly because the potential threat of imitation is greater than it is for other resources [22].

Table 4. Intellectual Property (Netmarble, 2018).

\begin{tabular}{ccccc}
\hline & \multicolumn{2}{c}{ Trademark } & \multicolumn{2}{c}{ Patent } \\
\cline { 2 - 5 } & Domestic & Overseas & Domestic & Overseas \\
\hline Enrolled & 232 & 131 & 12 & 1 \\
\hline Filed & 34 & 42 & 25 & 6 \\
\hline
\end{tabular}

Table created by the authors, Source: [18].

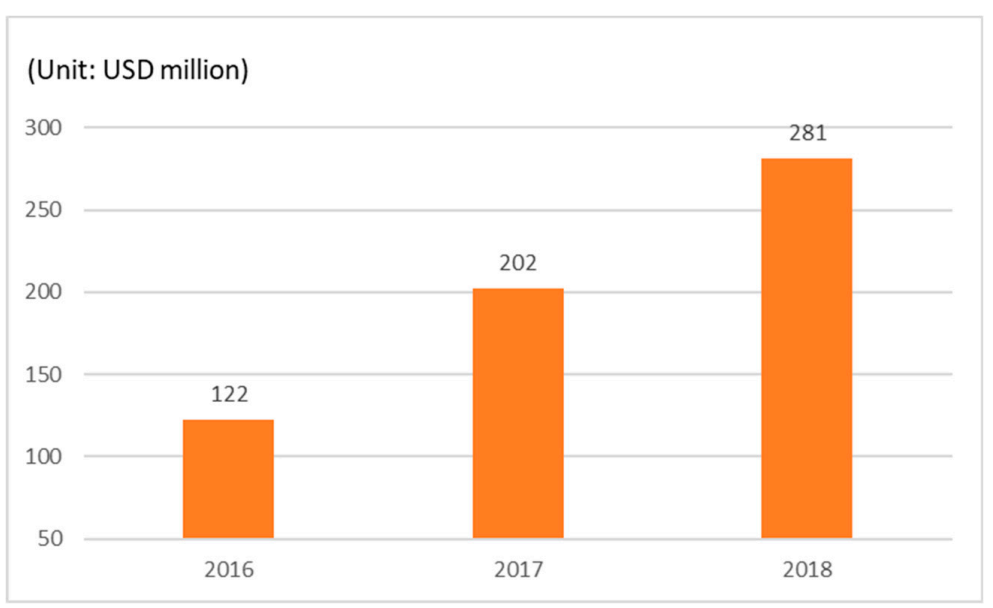

Figure 6. Loyalty Income (NCSoft, 2016-2018). Graph created by the authors. Source: [19]. 


\subsection{Summary of Findings}

Our findings are summarized in Table 5 . We first divided mutual forbearance into high and low levels. Next, for each situation, we mapped the actions across three different stages of innovation. Our analysis in Section 4.1 indicated that a high level of MMC was observed in Korea, and a low level of MMC was observed in both Japan and China. Therefore, we categorized Korea as a high mutual forbearance market, with the expectation that the rivalry between Netmarble and NCSoft would be decreased. In line with our expectation, under a high mutual forbearance situation, cooperative actions were found in both the content development and the content commercialization stages. A representative case was the product launch of the MMORPG game Lineage 2: Revolution. From the initial development stage, the game was co-developed by Netmarble and NCSoft, and their cooperation extended into joint marketing and promotion activities. Once the game became a commercial success, cooperative actions continued for regular game updates and server maintenance. However, a conflict between the two companies emerged slowly over time as they began a dispute over the IP rights.

Table 5. Summary of Findings.

\begin{tabular}{cccc}
\hline & $\begin{array}{c}\text { Content Development } \\
\text { (Low Observability) }\end{array}$ & $\begin{array}{c}\text { Content } \\
\text { Commercialization } \\
\text { (High Observability) }\end{array}$ & $\begin{array}{c}\text { Content Protection } \\
\text { (High Observability, } \\
\text { Mutual Forbearance } \\
\text { was Nullified) }\end{array}$ \\
\hline $\begin{array}{c}\text { High Mutual } \\
\text { Forbearance } \\
\text { (Korea) }\end{array}$ & $\begin{array}{c}\text { Cooperative Action: } \\
\text { Co-development }\end{array}$ & $\begin{array}{c}\text { Cooperative Action: } \\
\text { Joint marketing, } \\
\text { promotion }\end{array}$ & $\begin{array}{c}\text { Competitive Action: IPR, } \\
\text { Trademark, and Patent } \\
\text { filing Activities }\end{array}$ \\
\hline $\begin{array}{c}\text { Low Mutual Forbearance } \\
\text { (Japan, China) }\end{array}$ & $\begin{array}{c}\text { Competitive Action: IP } \\
\text { Acquisition }\end{array}$ & $\begin{array}{c}\text { Competitive Action: } \\
\text { Local Partnership }\end{array}$ & $\begin{array}{c}\text { Competitive Action: IPR, } \\
\text { Trademark, and Patent } \\
\text { filing Activities }\end{array}$ \\
\hline
\end{tabular}

Source: Analysis conducted by the authors.

Interestingly, in the content protection stage, we found that, similar to studies in the high-tech context, mutual forbearance was nullified. This reconfirms the findings of Theeke and Lee [3] who stated that the potential loss generated from IP protection failure can be greater than maintaining mutual forbearance. It was technically difficult to acknowledge the contribution portion of the jointly created trademarks and IPs; therefore, ownership of IP rights became a major point of disagreement. To preemptively protect their IPs, the two companies filed trademarks and design patents, which in turn, in some cases, advanced into a lawsuit between the two. Although the actions taken in this stage were highly visible (i.e., a lawsuit), the mutual forbearance mechanism did not work because the estimated loss incurred from losing the IP was greater than the rival's expected retaliatory actions.

Under a low mutual forbearance situation, as predicted, competitive actions were taken by the two companies. In the content development stage, more aggressive forms of competitive action, such as acquisition, were observed. For commercialization, the two companies sought competitive measures such as a local country partnership or establishing wholly-owned subsidiaries for publishing. Overall, the competitive dynamic between Netmarble and NCSoft was heightened in low mutual forbearance markets (Japan and China), compared to Korea. Preemptively filing trademarks and patents was also observed in low mutual forbearance markets.

\section{Discussion}

\subsection{Intended Theoretical Contributions}

This research aimed to shed new light on how MMC impacts different stages of the innovation process and suggest strategies for product development. In any industry that requires generative creativity, the commercialization of ideas, and protection of its IPs, it is crucial to understand how to develop defensive and offensive strategies [23] within the different stages of innovation. There 
is an intensified level of competition in the mobile game industry due to its fast market growth, which makes it critical for managers to understand how to manage cooperative interactions with their key competitors [24].

We refined existing studies on MMC by demonstrating that mutual forbearance hypothesis can be applied differently to upstream and downstream innovation activities. We found that the variances of observability and uncertainty that are associated with upstream and downstream activities lead to different competitive actions. Similar to Anand, Mesquita and Vassolo's [12] work on MMC and exploitation and exploration activities, our findings can also be understood as boundary to applying the mutual forbearance hypothesis. Our findings might also suggest that overseas ownership choices can be an outcome of intensified rivalry. As the entry mode differs in terms of visibility and protection of private information, firms tend to choose entry modes that are less visible and more protective under intensified rivalry. Few studies have theorized and argued different entry modes [20]; therefore, our approach extends the existing research in understanding the consequences of MMC in the context of international business management.

Lastly, this study contributes to studies related to innovation strategy on IP and knowledge protection. Beyond the existing studies that focus on organization and technological aspects, we suggest that IP or knowledge protection measures can be triggered by intensified rivalry in overlapping markets. Different types of knowledge, such as market knowledge, trademarks, and technology, as well as different methods, such as patents and licensing, which aim to protect each type of knowledge, were identified.

\subsection{Limitation and Avenues for Future Research}

Our research endeavors to open new avenues for future research by linking MMC and innovation at different stages. One of the major limitations of our research is its base on qualitative case research. We encourage scholars to take our ideas into empirical settings and reconfirm and/or refine our findings. Another contribution can also come from theorizing and testing different types of moderators, which can impose boundary conditions on our findings. For example, by analyzing data on loans in the Spanish banking industry, Mas-Ruiz and Ruiz-Moreno [21] found that firm-size effects work as a boundary to increased rivalry and performance. Considering that the content industry sees the continuous entry and exit of firms, firm-size heterogeneity can be a meaningful moderator. Other possible moderators include managerial cognition-related variables, such as the CEO's past decision-making pattern, tenure, and functional background. Since CEOs of Korean game firms are iconized and symbolized as the key decision makers, how these CEOs perceive and recognize MMC can moderate the consequences.

Theoretically, and following prior studies on MMC, we assume that the mutual forbearance hypothesis is the critical mechanism of MMC. Future studies can explore how different theoretical mechanisms emerge as either complementary or off-setting mechanisms to the mutual forbearance hypothesis. As Yu and Cannella [1] suggested, a large body of MMC studies are being conducted in a limited number of industries (e.g., the airline industry), and this may have narrowed the possibility of discovering other theoretical mechanisms. To increase the generalizability of the mutual forbearance hypothesis, replication or reconfirming the findings in diverse contexts is also warranted.

The Chinese Government's sanction against Korean game companies in 2017 suggested a new way of viewing regulation. According to our study, external shock or regulation has somewhat decreased the level of rivalry in China, leading firms to act less defensively toward one another. One area of possible future research is to conducting follow-ups to the Chinese Government's sanction to compare how a firm's actions change when the sanction is lifted. Scholars can also extend this topic by linking it to how institutional arrangements, along with MMC, influence firms' strategic reactions. For example, how do taxation, antitrust laws, or subsidies or sanctions influence competitive actions among rivals? The gaming or digital content industry is known to be sensitive to regulation, making it a suitable context for exploring such questions. 


\section{Conclusions}

The mobile game industry is one of the most economically important and fastest-growing sectors within the digital content industry. Despite its importance, few studies have investigated how cooperation and competition between mobile game companies occur in the different stages of innovation: content development, commercialization, and protection of IPs. By focusing on the competitive aspects of two rivals, we studied how the competition dynamics between MMC rivals influences their innovation strategies. From an in-depth case analysis of two leading companies in the Korean mobile game industry, we provide a framework explaining how mutual forbearance and observability of a rival's competitive action influences the choice of strategic decisions in different stages of innovation.

\subsection{Implications for Open Innovation Studies}

Open innovation is becoming an important source of innovation across different industries [22]. The nature of open innovation encourages multiple actors to engage in various stages of the innovation process; therefore, the findings of our study can be applied for further investigation. For example, cluster-based open innovation requires the coordination of architectural design in key activities among different stakeholders [25]. A varying degree of mutual forbearance and observability of activities may influence the level of tacit knowledge input [26], exploitation of the created knowledge, and leakage of the shared knowledge [27] among participants.

Ideas and feedback are interactively exchanged between diverse open-innovation channels, making the open innovation process especially beneficial for the entrepreneurial process; of identifying and seizing business opportunities. During the open innovation process, firms might encounter their competitors in various domains of activities, where multiple contacts between rivals can occur. Our research suggests that a cautious approach is warranted for understanding the competitive dynamics, depending on the observability and collusiveness of the competitors' actions. For instance, entrepreneurs can choose different types of channels for open innovation [28], based on their own evaluation of the potential channel partners, and the economic dynamics [29]. Open innovation channels can be about the partner's choice as well as the choice of the mode of collaboration (direct vs. indirect). Some recent studies have suggested that, in the high-tech industry, firms prefer MMC rivals as a prime candidate for technology development partners [30]. Therefore, we encourage future research to apply our framework to various types of entrepreneurial open innovation projects.

\subsection{Implications for Managers}

Our study offers several important practical implications for managers. We firstly suggest that competition is not always about the industry structure and/or the competitive landscape. Although there are often multiple competitors in the same industry, firms' behaviors can be influenced more by their key rivals in the same overlapping markets. Narrowing the scope of key rivals may help managers decide on their next competitive action. Key rivals may not necessarily be major players in the industry; they can also be small-sized competitors in overlapping markets.

In addition, when forming innovation strategies, managers should understand the different natures of both upstream and downstream activities in terms of their visibility and uncertainty. As prior studies on innovation and creativity have suggested, idea generation/development and commercialization require different organizational resources and processes [31,32]. Specifically, idea generation can be characterized by variation and the selection of new contents, whereas commercialization is more about building the right business model for each product. Managers should understand the multifaceted nature of innovation to build more effective strategies, per each stage of the innovation. For example, in converted industries, strategizing commercialization (i.e., the business model) might be more important, whereas in emerging industries, strategizing technology development in the early stage of the innovation might be more important [33]. 
Lastly, we also emphasize the importance of protecting knowledge assets to preserve a competitive advantage. Developing and protecting competitive IP is more important for managers in the digital contents industry simply because the cost of imitation is relatively low. Therefore, such managers should always recognize the importance of IP rights and the protection of knowledge.

Author Contributions: Conceptualization, J.L. and J.S.P.; formal analysis, J.L.; investigation, J.L. and J.L.; supervision, J.L.; visualization, J.S.P.; writing—original draft, J.L.; writing—review \& editing, J.S.P. and J.L. All authors have read and agreed to the published version of the manuscript.

Funding: This research received no external funding.

Conflicts of Interest: The authors declare no conflict of interest.

\section{References}

1. Yu, T.; Cannella, A.A., Jr. A comprehensive review of multimarket competition research. J. Manag. 2013, 39, 76-109. [CrossRef]

2. Kang, W.; Bayus, B.L.; Balasubramanian, S. The strategic effects of multimarket contact: Mutual forbearance and competitive response in the personal computer industry. J. Mark. Res. 2010, 47, 415-427. [CrossRef]

3. Theeke, M.; Lee, H. Multimarket Contact and Rivalry over Knowledge-based Resources. Strateg. Manag. J. 2017, 38, 2508-2531. [CrossRef]

4. Williams, D. Structure and competition in the US home video game industry. Int. J. Media Manag. 2002, 4, 41-54. [CrossRef]

5. Langley, A. Strategies for theorizing from process data. Acad. Manag. Rev. 1999, 24, 691-710. [CrossRef]

6. Eisenhardt, K.M. Building theories from case study research. Acad. Manag. Rev. 1989, 14, 532-550. [CrossRef]

7. Korn, H.J.; Baum, J.A. Chance, imitative, and strategic antecedents to multimarket contact. Acad. Manag. J. 1999, 42, 171-193.

8. Chen, M.-J.; Miller, D. Competitive dynamics: Themes, trends, and a prospective research platform. Acad. Manag. Ann. 2012, 6, 135-210. [CrossRef]

9. Gimeno, J.; Woo, C.Y. Multimarket contact, economies of scope, and firm performance. Acad. Manag. J. 1999, 42, 239-259.

10. Greve, H.R. Multimarket contact and sales growth: Evidence from insurance. Strateg. Manag. J. 2008, 29, 229-249. [CrossRef]

11. Gimeno, J. Reciprocal threats in multimarket rivalry: Staking out 'spheres of influence'in the US airline industry. Strateg. Manag. J. 1999, 20, 101-128. [CrossRef]

12. Anand, J.; Mesquita, L.F.; Vassolo, R.S. The dynamics of multimarket competition in exploration and exploitation activities. Acad. Manag. J. 2009, 52, 802-821. [CrossRef]

13. Porter, M.E. Towards a dynamic theory of strategy. Strateg. Manag. J. 1991, 12, 95-117. [CrossRef]

14. Glynn, M.A.; Lounsbury, M. From the critics' corner: Logic blending, discursive change and authenticity in a cultural production system. J. Manag. Stud. 2005, 42, 1031-1055. [CrossRef]

15. Hirsch, P.M. Cultural industries revisited. Org. Sci. 2000, 11, 356-361. [CrossRef]

16. Candy Crush Saga Creator King Gets Greedy and Trademarks the Word 'Candy'. Available online: https://www.independent.co.uk/life-style/gadgets-and-tech/candy-crush-saga-creators-king-getgreedy-and-trademark-the-word-candy-9074902.html (accessed on 23 January 2020).

17. Korea Creative Content Agency. Korea Content Industry Report; Korea Creative Content Agency: Naju, South Korea, 2018.

18. Financial Supervisory Service. Netmarble Annual Report; Financial Supervisory Service: Seoul, South Korea, 2018.

19. Financial Supervisory Service. NCSoft Annual Report; Financial Supervisory Service: Seoul, South Korea, 2018.

20. McGrath, R.G.; Chen, M.-J.; MacMillan, I.C. Multimarket maneuvering in uncertain spheres of influence: Resource diversion strategies. Acad. Manag. Rev. 1998, 23, 724-740. [CrossRef]

21. Mas-Ruiz, F.; Ruiz-Moreno, F. Rivalry within strategic groups and consequences for performance: The firm-size effects. Strateg. Manag. J. 2011, 32, 1286-1308. [CrossRef]

22. Chesbrough, H.; Crowther, A.K. Beyond high tech: Early adopters of open innovation in other industries. $R$ E D Manag. 2006, 36, 229-236. 
23. Han, J.; Cho, O. Platform business Eco-model evolution: Case study on KakaoTalk in Korea. J. Open Innov. Technol. Mark. Complex. 2015, 1, 6. [CrossRef]

24. Della Corte, V. Innovation through Coopetition: Future Directions and New Challenges. J. Open Innov. Technol. Mark. Complex. 2018, 4, 47. [CrossRef]

25. Yun, J.J.; Zhao, X.; Yigitcanlar, T.; Lee, D.; Ahn, H. Architectural design and open innovation symbiosis: Insights from research campuses, manufacturing systems, and innovation districts. Sustainability 2018, 10, 4495. [CrossRef]

26. Nonaka, I. A dynamic theory of organizational knowledge creation. Org. Sci. 1994, 5, 14-37. [CrossRef]

27. Park, N.K.; Mezias, J.M.; Lee, J.; Han, J.-H. Reverse knowledge diffusion: Competitive dynamics and the knowledge seeking behavior of Korean high-tech firms. Asia Pac. J. Manag. 2014, 31, 355-375. [CrossRef]

28. Yun, J.J.; Lee, M.; Park, K.; Zhao, X. Open innovation and serial entrepreneurs. Sustainability 2019, 11, 5055. [CrossRef]

29. Yun, J.J.; Won, D.; Park, K. Entrepreneurial cyclical dynamics of open innovation. J. Evol. Econ. 2018, 28, 1151-1174. [CrossRef]

30. Ryu, W.; Reuer, J.J.; Brush, T.H. The effects of multimarket contact on partner selection for technology cooperation. Strateg. Manag. J. 2019, 41, 267-289. [CrossRef]

31. Amabile, T.M. A model of creativity and innovation in organizations. Res. Organ. Behav. 1988, 10, $123-167$.

32. Woodman, R.W.; Sawyer, J.E.; Griffin, R.W. Toward a theory of organizational creativity. Acad. Manag. Rev. 1993, 18, 293-321. [CrossRef]

33. Yun, J.J.; Won, D.; Park, K.; Jeong, E.; Zhao, X. The role of a business model in market growth: The difference between the converted industry and the emerging industry. Techonol. Foreacsting Soc. 2019, 146, 534-562. [CrossRef]

(C) 2020 by the authors. Licensee MDPI, Basel, Switzerland. This article is an open access article distributed under the terms and conditions of the Creative Commons Attribution (CC BY) license (http://creativecommons.org/licenses/by/4.0/). 